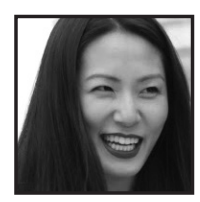

\title{
It Is All Part of the Process: Becoming Pedagogical Through Artful Inquiry
}

\author{
Eun-Ji Amy Kim, McGill University
}

\begin{abstract}
The experiences and challenges that teacher-educators go through tend to be private and go unnoticed (Berry \& Loughran, 2005). Through self-study, teacher-educators can reflect on their practices and learn from each other's practices. As a novice teachereducator who was teaching an inquiry-based teaching science methods class with a collaborative teaching team, I explore my experience of being a teacher-educator through arts-based self-study. In this paper, I discuss how the process of artful inquiry informed my own research and teaching practices. Based on the idea of $a / r /$ tography, I link my artistic, research, and teaching practices together to explore what it means to be becoming pedagogical (Gouzouasis, Irwin, Miles, \& Gordon, 2013).
\end{abstract}

n this study, I share my experience as a novice teacher-educator in a collaborative teaching team through an arts-based self-study. Scholars, including Diamond and van Halen-Faber (2005), suggested that academic literature should play a role in changing the people who teach. However, as Berry and Loughran (2005) problematized, many underlying issues associated with changes and development for teacher-educators are private and go unnoticed. They suggested teacher-educators participate in self-study as "an approach . . . to critically examine their own beliefs about teacher education through challenging their existing practice in meaningful ways" (p. 187). In particular, arts-based self-study allows educators to reflect on their practices and transform their learning into the construct of becoming pedagogical, which connotes "a [constant] state of coming to know through embodied living inquiry whereby the learner [educator] is committed to learning 
... with an emphasis placed upon creative flow" (Gouzouasis et al., p. 8). For this self-study, I focus on a/r/tography, an arts-based methodology that provides "the artist/teacher/researcher a way to postulate and write about the multiple positions that they embody" (Carter, 2012, p. 2). Gouzouasis and colleagues (2013) suggested that by connecting their personal experiences and society through $a / r /$ tography, educators could experience becoming pedagogical through learning skills of observations, questioning, analysis, and interpretation. Through employing a/r/tography, I explore my beliefs about what it means to be a teacher-educator and the process of becoming pedagogical with the goal of assisting other, especially novice, teacher-educators.

In this paper, I describe my visual art-making, research, and teaching practices from September to December 2015, when I taught an inquiry-based science education method class in a collaborative teaching team. I start by exploring how our team incorporated inquiry-based teaching and how I came to this research project. Thereafter I share my stories as an artist, arts-based researcher, and teacher-educator and explain how the practices (artistic, research, teaching) inform each other.

\section{Context: Beginning the Journey of an A/r/tographer}

Today is the first day of class and my artful/teaching journey for the next 15 weeks. My emotions changed from being nervous to questioning, then to realizing "it [teaching and art-making] is all part of the process." (First journal entry, September 16, 2015)

My teacher-educator journey started with feelings of nervousness and uncertainty. As a PhD candidate and former secondary science teacher, I was teaching a course in elementary science teaching methods with a collaboratively run teaching team. This team consisted of one course lecturer, two lab instructors (teaching assistants), and one lab technician. Through our weekly meetings, we reflected on our teaching, and planned and readjusted our teaching activities and inquiries for class discussion. As a lab instructor, I taught two-hour inquiry-based, discussion-based labs for two groups of pre-service teachers. The lab was designed to build content knowledge and pedagogical knowledge about elementary science through employing a constructivist approach to inquiry-based learning.

Windschiltl, Thompson, and Braaten (2008) suggested that science education should focus on engaging "learners deeply with content and with the epistemic 
practices of authentic science" using a constructivist inquiry-based teaching approach. A constructivist perspective assumes that students must be actively involved in their learning and that concepts are not transmitted from teachers to students, but constructed by students (Bybee, 1997). This approach helps students learn science through "direct experience, consistently practicing the inquiry skills and seeking deeper understanding of science content" (Banchi \& Bell, 2008, p. 29). Windschitl and Thompson (2006) suggested that teacher education should focus on developing prospective teachers' understandings about teaching in a constructivist inquirybased manner. It is for this reason that inquiry-based teaching was employed by our collaborative team to teach elementary pre-service teachers both pedagogical and content knowledge of science. As a teacher-educator, I see the benefits of employing inquiry-based teaching for a methods course specifically for pre-service teachers, who often lack experience with the inquiry-based approach. This approach offers a substantive, tangible model of inquiry-based teaching and learning in science as well as a place for continuous discussion about strategies and discourse moves for effective delivery of inquiry-based teaching.

Trying an inquiry-based teaching approach to build knowledge with students and being unable to predict the end result made me nervous. Before my first class, I had many questions and doubts. I asked myself: "How would employing this method influence my identity as a teacher-educator?" I wanted to delve into this question throughout the process of teaching.

Collaboratively planning and reflecting on classes with other instructors was very new to me. Berry and Loughran (2005) highlighted the culture of isolation in teaching institutions that reinforces the message that "sharing questions or concerns about teaching is not something that teacher-educators do (or should do)" (p. 169). In turn, teacher educators' process of "learning to teach teachers is often experienced as a private struggle" (p. 169). Indeed, throughout my teaching career (at both secondary and university levels), I tackled the whole process by myself. Senior instructors and department heads provided advice, but I did all the planning, marking, and reflecting. For me, teaching was (and still is) a one-person show and in order to teach pre-service teachers, I thought I had to know the content perfectly to be the perfect teacher. Therefore, thinking of collaboratively working with pre-service teachers through inquiry-based learning and planning and reflecting on my practices with other instructors led me towards questions and anxiety, rather than comfort and certainty. What does collaborating with students and other educators really mean? How does it influence my teaching practices and my identity formation as a teacher-educator? One day, while walking around the faculty building thinking about these questions, 
I saw a sign on a bulletin board: "ArtHive: come make art with artist in residence." Without hesitation, I walked in.

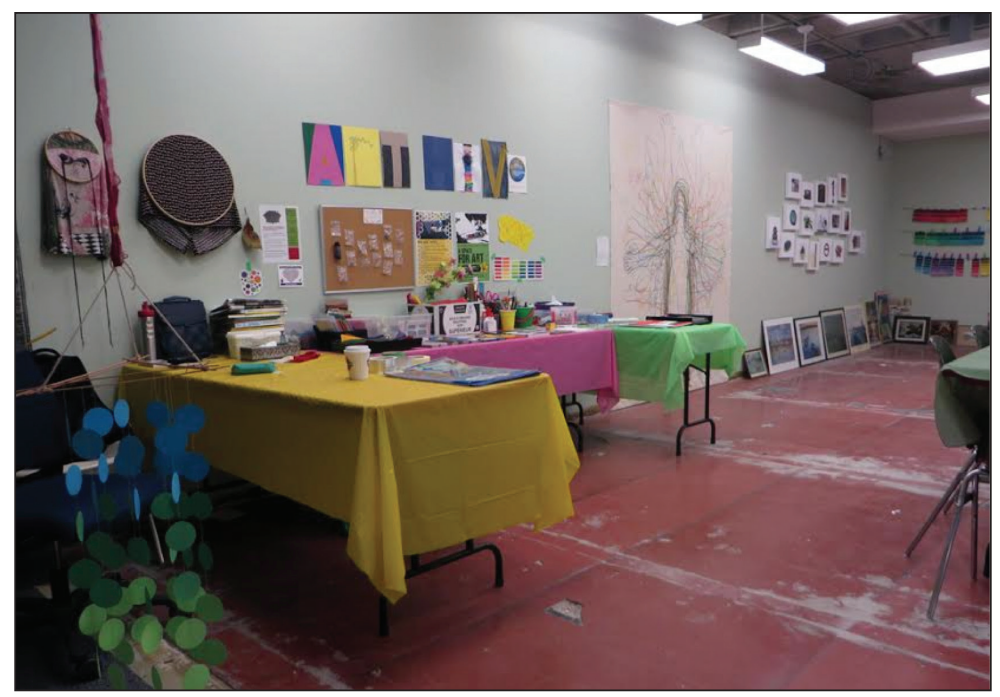

Fig. 1: Art hive

The artist in residence, Maria, ${ }^{1}$ greeted me with a big smile. There were brushes, beads, colourful paper, tools, and all sorts of beautiful raw materials ready to be transformed into art. I felt comfortable and began drawing and writing. My journey as an a/r/tographer had begun. Coincidental but apt.

\section{Theoretical Framework: A/r/tography as Living Inquiry}

$\mathrm{A} / \mathrm{r} /$ tography is an arts-based research methodology that reflects the creation of meaning and identities in the liminal spaces between art-making, researching, and teaching (artist/researcher/teacher) through living inquiry (Springgay, Irwin, \& Kind, 2008). A/r/tography as living inquiry strongly resonates with Derry's (2005) view of embodiment as "a way of knowing that goes beyond the intellectual, logical, and rational mode of thinking that has traditionally been defined as knowledge" (p. 35). 
Embodied encounters include "emotions, cultures, [and] physical sensations" (p. 35), the kinds of human experiences that McNiff (1998a) argued cannot be completely understood through the conventional scientific method, thus requiring "the process of aesthetic inquiry" (p. 15). This process of creative expression and interpretation allows a "hermeneutic dialectic between lived life and art: art interprets life and life interprets art" (Van Manen, 1984, p. 51). Artists give shape to their lived experience through the process of aesthetic inquiry, hence the products of art are "lived experiences transformed into transcended configuration" (Van Manen, 1990, p. 74). In this sense, I view an artist as a "person who creates things or experiences with the clear intention of making 'art'" through their living inquiry (M. Ezcurra, personal communication, January 27, 2016). Based on this notion of embodiment and a hermeneutic dialectic between lived life and art, a/r/tography offers processes for explorations—“ways of thinking, knowing, and doing that are rooted in the arts" (Gouzouasis et al., 2013, p. 8).

There are no specific procedures or methods for $a / r /$ tography; $a / r /$ tographers become the "creators and innovators of their own work" (Carter, 2012, p. 43) who explore their living inquiries emanating from their artistic, research, and teaching practices in a process that is purely organic. A/r/tographical work "grows and changes and it follows its own rhythm and direction based on its own necessity" through an aesthetic embodiment (M. Ezcurra, personal communication, January 15, 2016).

The organic process of a/r/tography results in what Wiebe et al. (2007) described as rhizomatic relations. Deleuze and Guattari (1987) explained the rhizomatic relations of different processes and/or products in their practices as artists, researchers, and teachers in a/r/tography (as cited in Wiebe et al., 2007). Rhizomes make different, connected entry points into a system, growing organically in multiple directions. In this light, a/r/tographical works allow an evolution of questions and meanings through making connections to different theories, processes, and products in their living inquiry (Carter, 2012). This allows processes, research questions, and artistic and pedagogical practices to inform one another as they evolve and grow together. These connections can be brought in harmony through writing.

$\mathrm{A} / \mathrm{r} /$ tography is a theoretical framework that allowed me to freely explore through my art-making, teaching, and researching processes connected to my class instruction. It also offered a place to reflect on my multiple practices, and relationships between myself and other instructors, as well as my different selves (i.e., artist, researcher, and teacher). 


\section{Methods: Arts-Based Self-Study}

Based on the ideas of $a / r /$ tography, I consider this work as an arts-based selfstudy. I employ the framework of self-study to understand the layers in the process of becoming a teacher-educator through artful inquiry. As Hamilton (2005) stated, "one of the hallmarks of self-study research is our [a/r/tographers'] willingness to hold our work up for others to examine... We both 'do' and 'show'" (p. 59). Self-study research allowed me to openly ask questions about my teaching practice, as I choose my "own research questions about something that captures [my] attention" (Samara, 2011, p. 5). Samara (2011) reminded us that "self-study research builds on the necessity of relationships between individual and collective cognition in the professional development of teachers and the power of dialogues in building a learning community of engaged scholarship" (p. 5). Thus, I chose to have three different groups of critical friends reflecting on the three aspects of $a / r /$ tography.

For the art and research aspects, the artist-in-residence, Maria, was my critical friend and spoke about my art-making process and the process of arts-based research. Before every lab session, I met with Maria to reflect on how I felt about teaching by creating visual art. I was not bound to a particular genre of visual art-making. I chose materials and techniques in "a more natural process of engagement relying on common sense decision making, intuition, and a general responsiveness of the natural flow of events and experiences"(Cole \& Knowles, 2008, p. 61). I let my feelings and questions about teaching emerge and evolve through the art-making process. After each session, I wrote reflections about my art-making and my teaching practices. After teaching, I wrote a post-reflection in which I linked my thoughts, experiences, and feelings about what happened in both classes as well as about what my art piece depicted.

For the teaching aspect, I had two different groups of critical friends. First, I explored the challenges and issues that arose with my collaborative teaching team. Second, I had a collaborative inquiry group consisting of six teacher-educators with different backgrounds and experiences specializing in a diversity of subjects. In this group, I focused on exploring what it means to be a teacher-educator outside of a science education context.

Through these conversations, my reflexive journals, and my art, I explored and made sense of the meaning that "circulates, moving in all directions simultaneously" (Springgay et al., 2008, p. 86). 


\section{Research Questions: Exploring Through Artful Inquiry}

My first project driven by artful inquiry began very naturally and coincidentally. I dropped into Maria's art-making space with no particular research plans. The research questions weren't formed, and the method wasn't planned. I was just there to check things out, and to overcome my nervousness before classes began. The questions, methods, and data all came together naturally, which I had not experienced before as a researcher.

As the classes progressed, I felt unsure and lacked confidence about my abilities to make art and conduct arts-based research and teach pre-service teachers, making me feel lost as I tried to figure out my identity as an artist and teacher-educator while letting artful inquiry take control of the research process (Figure 2).

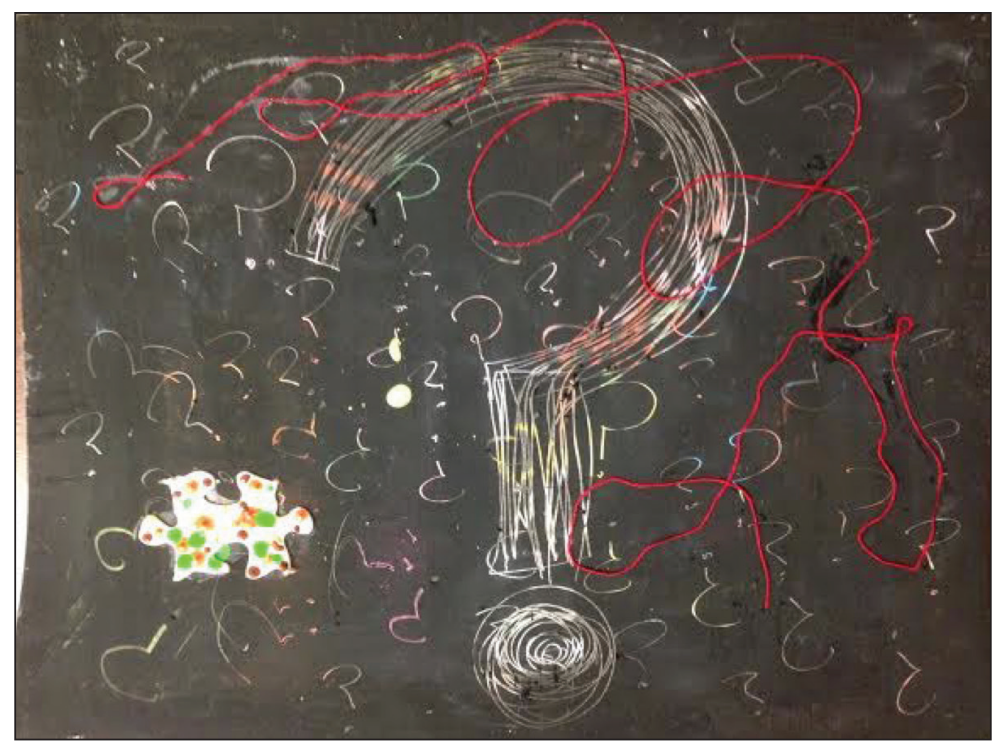

Fig. 2: Questions and a (lost) puzzle piece

I feel tension. Who do I feel tension with? With students? With Dawn [the instructor]? With myself? Also because of a focus on end results and outcomes, I feel like I am judged by students and the instructor. But the process is important, no? Or do I actually believe that? That it [the process] actually matters? 
The feelings and questions I had before teaching today are reflected in my art-making. Small arrows going up and down around question marks.... Well, do I know better than them [do I know have more knowledge than them]? Does that make me an expert? Maybe teacher-centered is not so bad after all? Wait, where does knowledge come from? Who does knowledge come from? Is knowledge built through a constructive process? Or does is come from me, the "teacher"?

Today, I am going into teaching with more questions than certainty. Maybe it is like the nature of science. You never know "for sure." With new evidence, scientific knowledge can change. Maybe with students' ideas, my way of thinking about teaching science will change. What does it mean to be a teacher-educator in a higher education setting? How does my art-making inform my teaching practice? Is it just mere meditation before class? To calm myself? Or elicit my feelings and emotions? How do they interact with each other? They are all relational but how does it transcend in practice? (Pre-teaching journal, September 23, 2015)

These questions were elicited and formed through my art-making and reflecting process. However, as time passed, I realized that as my identities changed, so did my practice. The questions also changed and evolved. For example, about 10 weeks into teaching, I realized that I was focusing more on the relations and changes created during $\mathrm{my}$ a/r/tographical process, rather than on what it meant to be collaborative in terms of teaching and learning. The evolution of my research question is aligned with Gouzouasis et al.'s (2013) notion of a "multidirectional view" for a/r/tography: as creative, artistic, and pedagogical inquiries often "reach out in to multiple directions before focusing on particular aspects of inquiry" (p. 3). As such, instead of focusing solely on a particular question, my research questions were formed, changed, and evolved organically through art-making.

While Eisner (1997) discussed the need to be precise and reduce ambiguity in artsbased research, Wilson (2004) asserted that, it is exactly "this ambiguity, complexity, and place of paradox that becomes ... a place of generative possibilities" (p. 57). Therefore, I stayed in the uncomfortable liminal spaces between the identities of "[my] artist/researcher/teacher selves as a way to understand [my] own creative and pedagogical positions" (Irwin, 2004, p. 39). 


\section{Findings: Focusing on Processes of Becoming}

Springgay (2004) suggested that identities are unfixed and uncertain. The artist, researcher, and teacher identities perform in relation to each other, and "bump and collide... . They push against each other, transgressing, shifting, and changing" (p. 74) in the liminal, undefined space that is "constantly in the process of becoming" (p. 65). In the context of becoming pedagogical, I concur with Carl Rogers's (1961) notion of becoming as a process involving "an increasing openness to experience" (p. $x x$ ). Thus, instead of focusing on one particular research question and method, I put emphasis on the process of becoming pedagogical (Gouzouasis et al., 2013) by committing to the state of constantly evolving and learning through creative flow. The findings of this study represent different stages of my process of becoming pedagogical through arts.

\section{Process 1: Becoming an Artist}

This section showcases the art produced in the process of becoming. I focus on what each piece depicts by linking them with my written reflection, therefore allowing new patterns of meaning to emerge (Springgay et al., 2008).

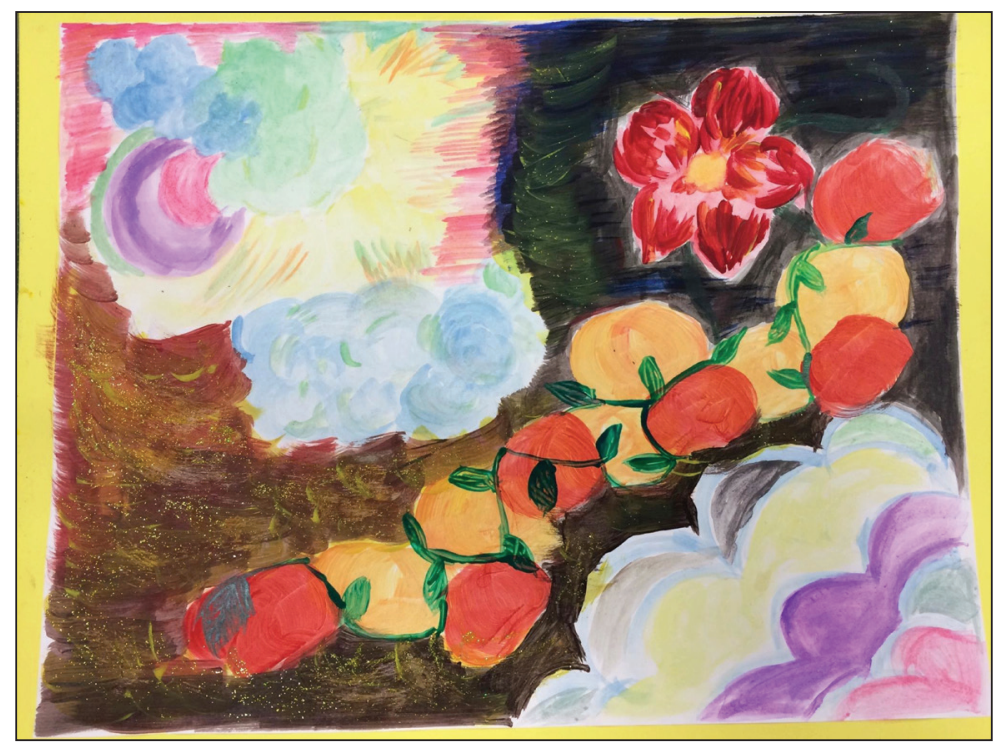

Fig. 3: Flower \& fruits in the sky 
I started colouring what appear to be clouds, very soft yet colourful. It reflects my mood. For once, I feel calm and ready to teach today's class. (Week 3, September 30, 2015)

I was very excited to come to my art section. It has become sort of meditative. I feel no anxiety toward my class or teaching today. This is reflected in my art. Instead of focusing too much on questions, I added flowers and apples. Though the background is black-ish night, it is never one colour. Incorporating sparkles, blue, red, yellow, the sky background represents pieces coming together. It is all part of something and it is the process that makes it fun. (Week 4, October 7, 2015)

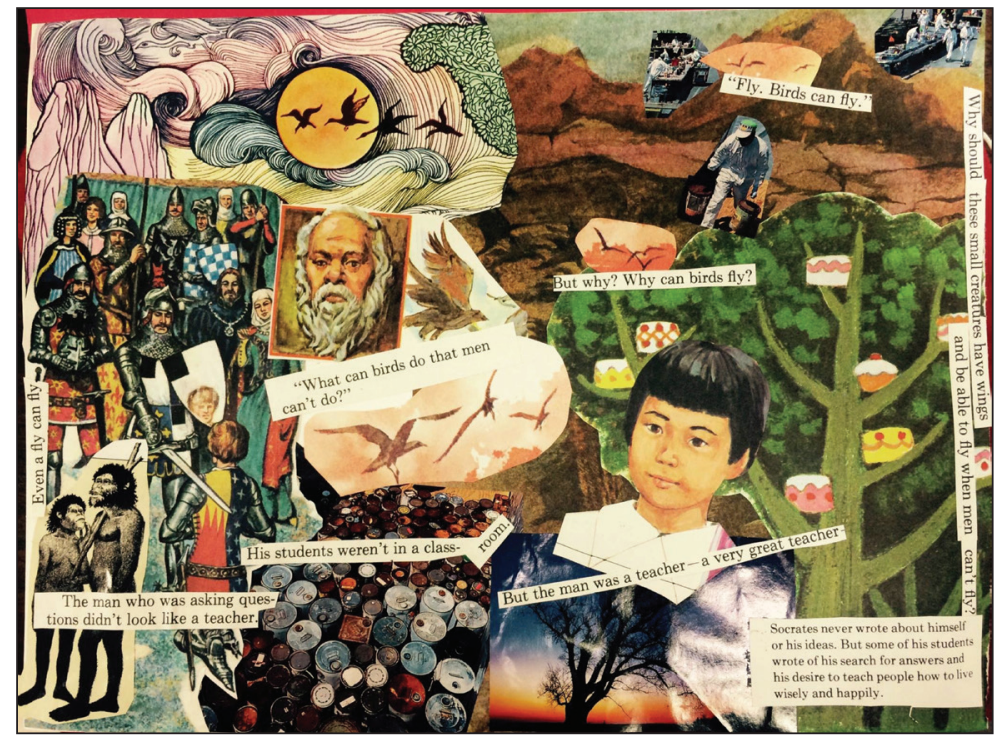

Fig. 4: In the midst of knights and Lucy the ape

I came across the Socrates story, which ends with the notion that Socrates was a real teacher though he didn't look like one and the students were not in a standard classroom. My question that emerged through this collage was: who is a teacher? Are teachers appointed to special roles, like knights? Who were the teachers amongst primitive humans? Perhaps, like the Socrates story tells us, learning can happen anywhere. As one can learn from nature, can anything in nature be a teacher? What happened to the constructivist point of view in teaching-building knowledge together with students and teachers? What are the roles of teachers in building knowledge together?

The closed paint cans represent compartmentalized knowledge in classroom teaching. As you can see above the mountain from far away, knowledge is made for students and 
delivered by teachers. The birds represent teachers. They can either deliver pre-made knowledge cans from the top of the mountains downhill to students or they can fly together and make knowledge as they travel. The tree represents the learning process. One tree has fruit; the other doesn't. Without fruit, the tree is still beautiful. Why do we focus so much on the outcome and product? The apple and the fruit? The process itself, growing, can be beautiful. The Asian child in the picture represents me. I am looking to the birds flying over the moon, as if trying to avoid the conventional way of teaching science, wanting to act based on my own beliefs, looking at the possibility that I do not have to follow the lesson plans, trying to answer the questions emerging from daily life, constructing knowledge with others. Is collaborative inquiry with my students possible?

Socrates didn't teach. He asked questions. His "search" and "desire" were taught naturally to students-a perfect example of curriculum-as-lived. Teacher as a learner through curriculum-as-lived. I totally get it now. (Week 5, October 14, 2015)

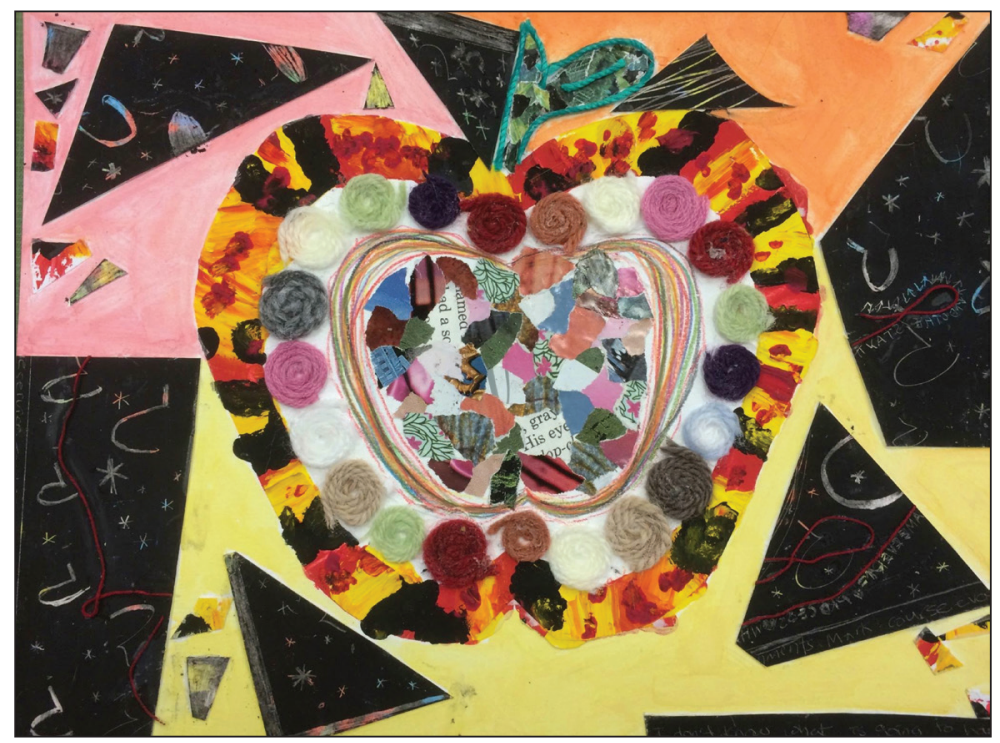

Fig. 5: Apple inside apple

I drew an apple, then used four different colours to fill the outer layer. Each colour had different brush strokes, representing different teaching pedagogies/strategies. I did a mosaic to depict different teaching philosophies. I wanted to show my tension about collaborative teaching. Though on the surface, the apple is still intact, the inner mosaic represents the tensions I feel in this collaborative inquiry and teaching process. My teacher-educator identity can be informed by others. How do I deal with 
the tension emerging from the experience? Could it be positive tension? Do I need tension and negotiation to build relationships with other instructors and students? (Week 6, October 21, 2015)

I added another layer that is threads in a circle. The circles have different textures, shapes, sizes, and starting and ending points. They are part of the process and together create another beautiful layer. . . . Though their [students'] works and thinking may not be scientifically accepted, I can see their relevance and significance. I will learn something from their work or the process of them becoming pedagogical. (Week 7, October 28, 2015)

I added another layer of different coloured lines to depict different perspectives individuals bring and the importance of being collaborative.... With the black puzzle piece from my first piece, I filled out the empty space on the other side of the apple, which represents the tensions I feel. Because the teaching inquiry process is collaborative, I may bring tension from physical tiredness or tension I feel with students, etc. When I was finished, I was not happy. It was just not pretty. It was just too much. I am going to see what happens to my art piece next week. In the end, it is all part of the process. (Week 9, November 11, 2015)

\section{Process 2: Becoming an Arts-Based Researcher}

When the semester was over, I began to write this article. I decided to perform a thematic analysis of written reflections. Lea, Belliveau, Wager, and Beck (2011) stated that $a / r /$ tography allows practitioners to reflect on different tensions they feel and experience during the process of art-making, research, and teaching and "critically writ[e] about these moments as they emerge" (p. 3). I believe that writing ties together my art-making, teaching, and conversations with my critical friends. Hence, I focused on written reflection as a main vehicle to find emerging themes on my process of becoming pedagogical. A few themes emerged, such as my identity as teacher vis-à-vis learner, tensions I felt during the collaborative teaching process, and my identity as an artist. However, I could not find ways to connect the themes. As rhizomes, the themes and meanings were literally all over the place. Through the lens of the multidirectional view (Gouzouasis et al., 2013; Carter, 2012), the inquiries and meanings I came across from the aesthetic encounters and teaching were widespread and evolved so much that I felt lost. I couldn't connect the findings harmoniously through writing. 
I spoke with Maria about my dilemma. She told me to refer back to my art pieces: "Do not focus too much on your written reflection. Try to find commonalities emerging from your art" (personal communication, January 16, 2016). Maria's advice was in line with Springgay et al.'s (2008) suggestion that scholars "need to examine art ... from the perspective of unravel[ing] the implications of the work relationally. This relational understanding ... shapes the methodology of a/r/tography" (p. 84). Thus, I participated in "qualify[ing] qualities ... creat[ing] qualitative relationships among component qualities" (Eisner, 2008, p. 8). To Eisner (2008), the materials used in art are converted into a medium, which mediates the researcher's observation and culminates in a form that brings the artist-researcher back to the experience and emotions the artist-self intended to disclose (p. 8).

Looking at the art pieces, I asked, what if emerging commonalities from art do not answer my inquiry? To this, Maria advised, "stay in [the] intuitive and creative process for research as well. Just like how you did when you were making art" (personal communication, January 7, 2016). Similarly, Diamond and van Halen-Faber (2005) suggested, "intuitive folding and conscious unfolding" of understandings and thoughts assert "a poetic and visual sixth sense that transforms us [researchers]" (p. 92).

Embracing the creative and intuitive process of research, as a researcher, I found myself exploring the liminal spaces between $\mathrm{a} / \mathrm{r} / \mathrm{t}$ by engaging in the iterative process of meaning-making through art pieces, teaching practices, literature, and conversations with my critical friends. For Carter and Irwin (2014), this is the process of living inquiry. Living inquiry as a/r/tographical rendering allows one to take time to "slow down [and] move towards resonance and poetic ways of being that unfold levels of intensity that can be forgotten or ignored when one rushes through life, communications, and experiences" (pp. 16-17). By taking time to think more deeply, letting artful inquiry along with creativity and intuition take control of the research process, and deeply engaging in the iterative process between $\mathrm{a} / \mathrm{r} / \mathrm{t}$, I experienced that "the spaces in-between these [artist, researcher, and teacher selves] disappear, instead strengthening each identity by allowing for new directions, approaches, ideas to emerge" (p. 4). As McNiff (2008) explained, when a person stays with the creative process, the process generates the unexpected. Commonalities between art pieces came very naturally, unlike the thematic analysis I attempted with written reflection. The unexpected in the research process illuminated a new understanding of my teaching practice. 


\section{Process 3: Becoming a Teacher-Educator}

I came across two major commonalities in the art pieces (Figures 2, 3, 4). They incorporated things from nature, such as trees and sky, and consisted of different fragments. Looking more closely, I attempted to "find and explore new patterns of meaning" as they emerged (Springgay et al., 2008, p. 89).

1. The organic nature of teaching: Trusting the process. Exploring the nature aspects of each piece allowed me to engage, understand, and embrace the organic nature of teaching. I drew from Ezcurra's notion of organic-“"following its own rhythms based on its necessity" (personal communication, January 15, 2016) and added that the organic nature of teaching (research and art-making) involves educators letting go. This notion of "surrender and let[ting] go of control" (Wilson, 2004, p. 28) leads us to the creative process. Letting go of control involves "trusting the process [which] is based on a belief that something valuable will emerge when we step into the unknown" (McNiff, 1998b, p. 27). Going into class every week and being unable to predict the teaching outcome was like entering unknown territory for me.

Through artful inquiry, I have started to understand and unpack this notion of "trusting the process" as well as the beauty of process, rather than outcomes in teaching. As seen in Figure 4, some trees have fruits but some don't. However, just because some trees don't have fruit, doesn't mean that the tree cannot be seen as beautiful. Indeed, plants like the apple tree represent growth and vitality, and the different apple images represent teachers and education. For Diamond and van Halen-Faber (2005), "impermanence of . . . fruits (and flowers) [represents the] fragility and vulnerability that attend development" (p. 84).

While I agree, the organic process of teaching - the process of the growth of the tree and the relations the trees have with others in nature that influence the growth of the tree-must be recognized rather than focusing solely on the outcome-the fruits. This was reflected in my written reflection while working on Figure 3. I did not like the colour combination. However, I reflected,

... being process-driven is more important and now I have started to appreciate the process more than the outcome... Today, students might not understand the material and the class might not go as planned, but I will enjoy the inquiry, the interaction, the challenge, and the inability to predict. (Week 4, October 7, 2015)

I have learned to let go of control in my artistic and teaching practice. This doesn't necessarily mean letting go of control of the classroom. Rather, it represents tuning 
oneself into the process, in the moments and conversations with students, and trusting the creative process in teaching practice that is illuminated from embracing the unknown. Letting go of control reflects curriculum-as-lived, which is "unplanned and unplannable" and "experienced by students and teachers as they live" (Aoki, 2000, p. 322). Letting go of control led me to experience curriculum-as-lived:

Though I felt anxious in the beginning of the first class, I noticed that anxiety was gone as I channelled more into the conversations with the students. . . When I was going over the discourse moves I used with the students, I realized, and admitted, that I didn't use one particular discourse move. I think it was the first time I shared with my students about "my failures/mistakes" as their teacher. ... When a teachable moment emerged in the class, I turned to pre-service teachers to explore the phenomenon together. I am becoming more comfortable being collaborative with my students in learning and constructing knowledge and experience together. (Week 6, October 21, 2015)

This was also the first time in my teaching career I let go of the pressure of being a perfect teacher and started to accept my identity as teacher vis-à-vis learner. Like trees, fruits, and birds, things in nature continue to grow. Porter (2004) stated teacher-educators need to "model lifelong learning [which] gives students reasons to learn beyond marks. We all become learners asking questions in a classroom where the primary goal is to help each other find the answers" (p. 111). Embracing my role as teacher vis-à-vis learner allows me to trust the continuous process of constructing knowledge with my students where "more meaningful connections among teachers, students, and subject matter" (p. 124) are being made. From their self-studies, Diamond and van Halen-Faber (2005) also asserted that in the research project that emerged from their teaching and artistic projects, they confirmed "once again" their identities as "a teacher-of-teachers and a learner-of-my-own-learning" (p. 92). As for me as well-if it wasn't for my artistic practice, I would never have realized the organic, letting-it-go process of teaching.

2. The fragments of identities: Re-weaving understandings. The art pieces consist of different fragments. In Figure 2, different colours used for the clouds and sky, and the contrast between the pastel colours of the fuzzy clouds and fruits and the bright vivid colours of the flowers, make one piece. Figure 3 and Figure 4 consist of different pictures and/or types of materials. Looking at different fragments across these art pieces led me to unpack my experience and relationship to collaborative teaching with other instructors. 
Initially, when working in a collaborative teaching team I felt like I needed to meet the instructional goals for each lesson and be perfect-because I understood collaboration as the completion of my part for the community. Being in such a team makes your teaching public to not only students, but also other instructors. This notion of "making private public" (Pente, 2004, p. 97), which invites collaboration as well as criticism, made me uncomfortable. In the liminal spaces between me and other instructors, I felt tension, as I reflected in week 2: "Owning my class. Is it my class? Or is it Dawn's (lecture instructor) class? Or is it "our class"?" I also discussed the personal tension I felt from reflecting on our practices together.

I found myself reluctant to listen and accept Sara's [the other lab instructor] comments when I brought up the issues of students talking and disturbing others. ... Sara gave me the same feedback as my other inquiry group.... Why? (Week 4, October 7, 2015)

As I partook in the $\mathrm{a} / \mathrm{r} /$ tographical process of understanding my teaching practices, I realized that as each of $\mathrm{my} \mathrm{a} / \mathrm{r} / \mathrm{t}$ identities were brought to "being through encounters with other beings:" it was my collaborative teaching team "that maintain[ed] both the contiguity and the distinctiveness of each pattern [of individual teaching philosophy and teaching]," yet informed each other's practices and grew together (Springgay et al., 2008, p. 86). The tension I felt with other instructors became a new form of understanding, as seen in my final reflection:

I am grateful that I had such a wonderful teaching team from whom I learned a lot. I used to go to Sara's class to observe if the activities work well and the flow of class discussion. I didn't tell her what to do-because it was her class. Although we teach collaboratively, and Dawn is the course instructor, it was Sara's class. Collaborative teaching informs each other's progress, and the activity planning, but there are still boundaries. "Owning own's class" is still there. (Week 12, December 2, 2015)

Albeit the contiguity between fragments in art still remain, the separate fragments make one art piece. Through reflecting and planning with others, I am re-weaving my understanding and experiences in teaching into a new form. Collaborative teaching requires letting go, trusting the unknown, and embracing the process of being "collaborative."

Our team had diverse education backgrounds and teaching experience. To create art, I selected pieces, and assembled them aesthetically. As an artistic way of knowing, teaching is a performative way of knowing thatartists and teachers select, do, and show (Hamilton, 2005). As my identity as a teacher-educator evolved, 
so did other instructors' identities and philosophies. Our collaborative teaching team, as a community, was "re-imag(e)-ined as a set of circumstances [individuals] that are not fixed but are ever evolving" (Springgay et al., 2008, p. 83). We, as a teaching team, were all part of the relationships and part of the creative process - teaching - together. Just as different fragments and layers in art pieces come together as one creative product, my a/r/t identities inform each other and teacher-educators collaborate and inform each other.

McNiff (2008) outlined "talking is a way of thinking and knowing [where] important insights emerge from the flow of conversation focused on a particular experience" (p. 36). He valued the "spontaneity" of evoking different perspectives during the process of sharing, which creates a new understanding that is overshadowed when individuals attempt to collect thoughts in isolation (McNiff, 2008). As a continuously evolving community, our teaching team is part of our relations to ourselves and others and the process of becoming pedagogical together. As seen in Figure 2, "incorporating sparkles, blue, red, yellow - the sky background represents pieces coming together. It is all part of something and it is the process that makes it fun" (Week 4, October 7, 2015).

\section{Continuing an Ongoing, Open-Ended Process}

Through this arts-based self-study, I learned the relationship between artistic, research, and teaching practices. I witnessed the reciprocal process between these practices and how they inform one another. Through making connections between my practices, I explored and learned the benefits of being process-driven rather than outcome-driven, letting go in my a/r/t practices, as well as the beauty of the contiguous, evolving nature of my identities and the teaching community I am part of. I view this article as living inquiry - an "embodied engagement with the world" (Gouzouasis et al., 2013 , p. 3). The lessons I learned, identities I constructed, and visual arts and written reflections produced through this study will also continue to evolve as readers comment on, and I reread, this article. The article itself is my way of engaging with the world, thus continuing to be in the process of becoming pedagogical. I conclude with my final reflection essay, wherein I reflect on the nature of being in a continuously evolving process of learning. 


\section{Final Tension and Ongoing Learning}

Throughout this journey, my research questions have been evolving. As I looked at my journals and art again, the themes arose-yet didn't quite answer the formed research questions. The data itself generated its own findings. Questions themselves also evolved as my a/r/tographer identities evolved. I also can't seem to finish my apple inside apple piece, which I wanted to be the closing piece that would summarize my becoming pedagogical process.

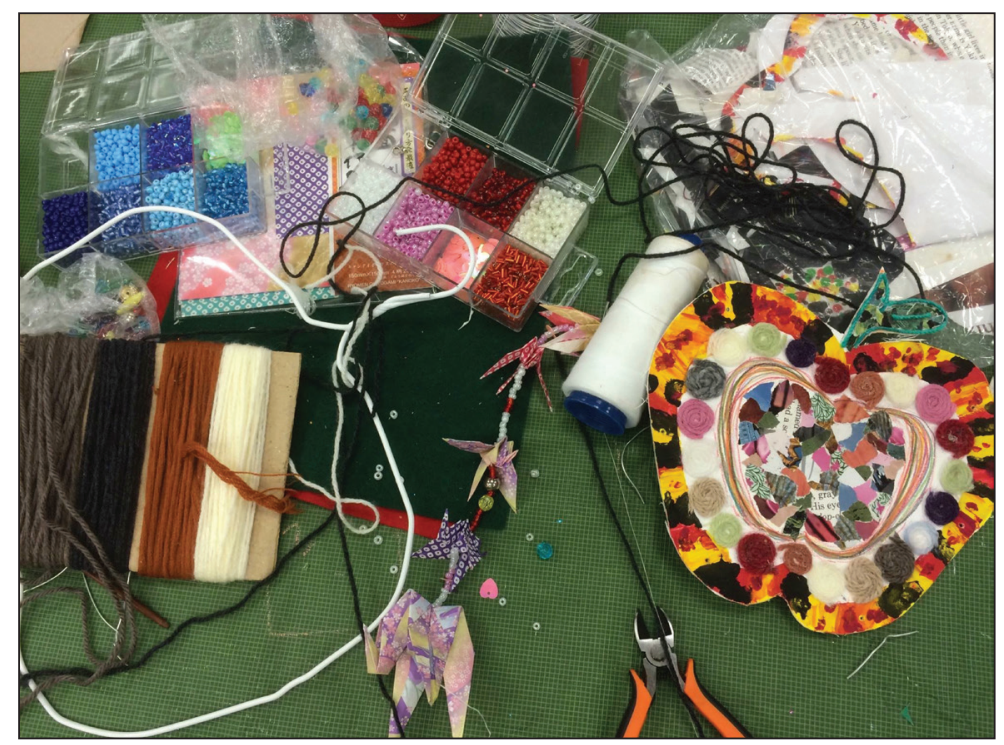

Fig. 6: A messy process

When I spoke to Maria about the tension I feel about having closure, she said: "Amy you don't have to finish the piece. It is still ongoing. It is open-ended process. It's a reciprocal process. They feed each other-your art and writing. It is a more organic process. Writing this paper finishes the first stage of the process. Writing and getting feedback from readers will inform your artistic, research, teaching practices" (personal communication, January 15, 2016). She suggested that I try to free-write. She said, "write everything freely and see what happen, write like you make your art. Use intuition" (personal communication, January 15, 2016). This is how I am writing now. I followed my intuition and made art freely, and writing let the feelings and lessons emerge to the surface. For me, artful inquiry led to growth in artistic, writing, arts-based research and teaching, as well as understanding and creating a teaching community that I go to for reflection and growth. 
A new semester has started. In my current role as an instructor of a secondary science teaching method course, I am not nervous like I was before. I understand now that it is all part of the process.

\section{Note}

1. Maria Ezcurra gave full permission to identify her by name and use direct quotations from our conversations. She reviewed the quotations before submission.

\section{References}

Aoki, T. (2000). Language, culture and curriculum. In W. F. Pinar, \& R. Irwin (Eds.), Curriculum in a new key (pp. 321-332). Mahwah, NJ: Lawrence Erlbaum Associates.

Banchi, H., \& Bell, R. (2008). The many levels of inquiry. Science and Children, 46(2), 26-29.

Berry, A., \& Loughran, J. (2005). Teaching about teaching: The role of self-study. In C. Mitchell, K., O'Reilly-Scanlon, \& S. Weber (Eds.), Just who do we think we are?: Methodologies for autobiography and self-study in education (pp. 168-180). New York: Routledge Falmer.

Bybee, R. W. (1997). Achieving scientific literacy: From purposes to practices. Portsmouth, NH: Heinemann.

Carter, M. R. (2012). The teacher monologues: Exploring the experiences and identities of artist-teacher (Doctoral dissertation). Retrieved from the University of British Columbia Data Base.

Carter, M. R., \& Irwin, R. L. (2014). Between signification and illumination: Unfolding understanding of an $\mathrm{a} / \mathrm{r} / \mathrm{tog}$ raphical turn on practicum. International Journal of Education \& the Arts, 15(3). Retrieved from http://www. ijea.org/v15n3/

Cole, A. L., \& Knowles, J. G. (2008). Arts-informed research. In J. G. Knowles, \& A. L. Cole (Eds.), Handbook of the arts in qualitative research:
Perspectives, methodologies, examples, and issues (pp. 55-70). London: Sage Publications.

Deleuze, G., \& Guattari, F. (1987). A thousand plateaus: Capitalism and schizophrenia. Minneapolis, MN: University Press.

Derry, C. (2005). Drawings as a research tool for self-study: An embodied method of exploring memories of childhood bullying. In C. Mitchell, K., O'Reilly-Scanlon, \& S. Weber (Eds.), Just who do we think we are?: Methodologies for autobiography and selfstudy in education (pp. 34-46). New York: Routledge Falmer.

Diamond, P., \& van Halen-Faber, C. (2005). Apples of change: Arts-based methodology as a poetic and visual sixth sense. In C. Mitchell, K., O'Reilly-Scanlon, \& S. Weber (Eds.), Just who do we think we are?: Methodologies for autobiography and self-study in education (pp. 81-94). New York: Routledge Falmer.

Eisner, E. (1997). The enlightened eye: Qualitative inquiry and the enhancement of educational practice (2nd ed.). New York: Merrill Publishing Company.

Eisner, E. (2008). Art and knowledge. In J. G. Knowles, \& A.L. Cole (Eds.), Handbook of the arts and in qualitative research: Perspectives, methodologies, examples, and issues (pp. 3-12). London: Sage Publications. 
Gouzouasis, P., Irwin, R., Miles, E., \& Gordon, A. (2013). Commitments to a community of artistic inquiry: Becoming pedagogical through $\mathrm{a} / \mathrm{r} /$ tography in teacher education. International Journal of Education \& the Arts, 14(1). Retrieved from http://www.ijea.org/ v14n1/

Hamilton, M. L. (2005). Using pictures at an exhibition to explore my teaching practices. In C. Mitchell, K., O'Reilly-Scanlon, \& S. Weber (Eds.), Just who do we think we are?: Methodologies for autobiography and selfstudy in education (pp. 58-68). New York: Routledge Falmer.

Irwin, R. L. (2004). A/r/tography: A metonymic métissage. In R. L. Irwin., \& A. de Cosson (Eds.), A/r/tography: Rendering self through arts-based living inquiry (pp. 27-40). Vancouver, BC: Pacific Educational Press.

Lea, G. W., Belliveau, G., Wager, A., \& Beck, J. L. (2011). A loud silence: Working with research-based theatre and a/r/tography. International Journal of Education \& the Arts, 12(16). Retrieved from http://www.ijea.org/ v12n16/

McNiff, S. (1998a). Art-based research. London: Jessica Kingsley.

McNiff, S. (1998b). Trust the process: An artist's guide to letting go. Boston: Shambhala.

McNiff, S. (2008). Arts-based research. In J. G. Knowles, \& A. L. Cole (Eds.), Handbook of the arts and in qualitative research: Perspectives, methodologies, examples, and issues (pp. 29-40). London: Sage Publications.

Pente, P. (2004). Reflections on artist/researcher/ teacher identities: A game of cards. In R. L. Irwin, \& A. de Cosson (Eds.), A/r/tography: Rendering self through arts-based living inquiry (pp. 91-102). Vancouver, BC: Pacific Educational Press.

Porter, N. (2004). Exploring the making of wonder: The a/r/tography model in a secondary art classroom. In R. L. Irwin, \& A. de Cosson (Eds.), A/r/tography: Rendering self through arts-based living inquiry (pp. 103115). Vancouver, BC: Pacific Educational Press.
Rogers, C. (1961). On becoming a person: A therapist's view of psychotherapy. London: Constable.

Samara, A. P. (2011). Self-study teacher research: Improving your practice through collaborative inquiry. London: Sage Publication.

Springgay, S. (2004). Body as fragment: Artmaking, researching, and teaching. In R. L. Irwin, \& A. de Cosson (Eds.), A/r/tography: Rendering self through arts-based living inquiry (pp. 60-74). Vancouver, BC: Pacific Educational Press.

Springgay, S., Irwin, R. L., \& Kind, S. (2008). $\mathrm{A} / \mathrm{r} /$ tographers and living inquiry. In J. G. Knowles, \& A. L. Cole (Eds.), Handbook of the arts and in qualitative research: Perspectives, methodologies, examples, and issues (pp. 83-92). London: Sage Publications.

Van Manen, M. (1984). Practicing phenomenological writing. Phenomenology and Pedagogy, 2(1), 36-39.

Van Manen, M. (1990). Researching lived experience: Human science for an action sensitive pedagogy. London, ON: The Althouse Press.

Wiebe, S., Sameshima, P., Irwin, R., Leggo, C., Gouzouasis, P., \& Grauer, K. (2007). Re-imagining arts integration: Rhizomatic relations of the every. The Journal of Educational Thought, 41(3), 263-280.

Wilson, S. (2004). Fragments: Life writing in image and text. In R. L. Irwin, \& A. de Cosson (Eds.), A/r/tography: Rendering self through arts-based living inquiry. (pp. 41-59). Vancouver, BC: Pacific Educational Press.

Windschitl, M., \& Thompson, J. (2006) Transcending simple forms of school science investigations: Can pre-service instruction foster teachers' understandings of modelbased inquiry? American Educational Research Journal, 43(4), 783-835.

Windschitl, M., Thompson, J., \& Braaten, M. (2008). Beyond the scientific method: Model-based inquiry as a new paradigm of preference for school science investigations. Science Education, 92(5), 941-967. 


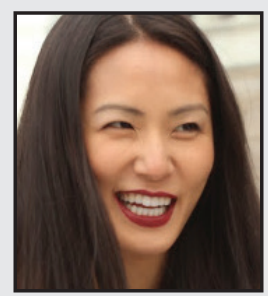

Eun-Ji Amy Kim is a PhD candidate in the Department of Integrated Studies in Education at McGill University. Her current research interests include Indigenous science education, STEAM education, and Aesthetics in science education. Following her passion for education, culture, and making a difference in her community, Amy has worked as a science workshop facilitator, a recreational assistant, and also mentored in First Nation reserves of the Anishinabe nations based in Ontario, Canada. A former secondary science teacher, Amy is currently collaborating with teachers and pre-service teachers on various research projects throughout Quebec, one of which is a project exploring pre-service teachers' views on Nature of Science through aesthetic inquiry. 